Editorial

\title{
Introduction to Nanomedicine
}

\section{Didier Astruc}

Received: 15 December 2015 ; Accepted: 15 December 2015 ; Published: 22 December 2015

Academic Editor: Derek J. McPhee

ISM, University of Bordeaux, 351 Cours de la Libération, 33405 Talence Cedex, France; didier.astruc@u-bordeaux.fr; Tel.: +33-5-4000-6271; Fax: +33-5-4000-6994

Although mentions of nanoparticles in relation to biomedicine appeared in the late 1970s and are now the subject of over 10,000 publications per year, the term "Nanomedicine" only appeared at the turn of this century, and less than 30 papers including this term were published up to 2005. Ten years later, Web of Science indicates the publication of more than 1000 Nanomedicine articles in 2015 among more than ten times more articles involving nanoparticles for biomedical usage. Nanomedicine has been defined by the European Science Fundation's forward Look Nanomedicine as follows: "Nanomedicine uses nano-sized tools for the diagnosis, prevention and treatment of disease and to gain increased understanding of the complex underlying patho-physiology of disease. The ultimate goal is to improve quality of life." [1]. It involves the three nanotechnology areas of diagnosis, imaging agents and drug delivery with nanoparticles in the 1-1000 nm range, bioships (from both "top-down" and "bottom-up" sources) and polymer therapeutics [2,3]. A relevant more recent terminology is that of "theranostics" $[4,5]$ involving both diagnostics and therapy with the same nanopharmaceutics.

In fact, Nanomedicine can be traced back to the use of colloidal gold in ancient times [6,7], but Metchnikov and Ehrlich (Nobel Prize for Medicine in 1908) are the modern pioneers of nanomedicine for their works on phagocytosis [8] resp. cell-specific diagnostic and therapy [9]. Seminal works on nanoparticles for nanomedicine were increasingly developed in the last 30 years of the 20th century and included liposomes [10,11], DNA-drug complexes [12], polymer-drug conjugates [13], antibody-drug conjugates [14], polymer nanocapsules [15-17], polymer-protein conjugates [18], albumin-drug conjugates [19], block-copolymer micelles [20], anti-arthritis gold nanoparticles [21] and anti-microbial silver nanoparticles [22]. These nanomedicines have various size ranges that are often not strictly within the standard definition of the nanoworld that is 1-100 $\mathrm{nm}$ [23]. Clinical toxicities including side effects have been broadly studied and sometimes point toward patient individualization.

Problems that need be overcome are that most drugs are neither specific nor water-soluble. The above nanocarriers have been designed to first solubilize drugs in aqueous media, then serve as nanovectors toward specific targets and control drug release. A majority of nanocarriers used now allow oral drug delivery. Although these nanovectors are designed to translocate across the gastro-intestinal tract, lung, and blood-brain barriers, the amount of drug transferred to the organ is lower than $1 \%$, therefore improvements are challenging [24,25]. Nanovector-drug assemblies are designed to maximize the benefit/risk ratio, and their toxicity must be evaluated not only by sufficiently long term in vitro and in vivo studies, but also pass multiple clinical studies. For biological assays, these nanomaterials must be characterized very strictly in a fully reproducible way [26,27]. Suitable nanocarriers (including metabolites) must be subjected to research of their antigenicity, immunotoxicity and possible activation of complements (that are a group of serum proteins that activates inflammation, destroys cells and participates in opsonization), pharmacokinetics, biodistribution, and drug release rates [28].

Tumor targeting drugs are a major focus in this context, and they use liposomes, polymers, micelles, conjugates, nanoparticles and conjugates of these nanopharmaceutics [29]. Two main routes are passive targeting using the enhanced permeation and retention (EPR) effect $[30,31]$ and active targeting involving covalent drug attachment using linkers to a receptor that should be specifically recognized by the cancer cells [32]. Drug release rates and stability until the targeted cells are 
reached are key factors. Imaging using gamma cameras, magnetic resonance (MRI), position emission tomography (PET) and near infrared (NIR) luminescence and fluorescence are major techniques allowing one to quantize drugs in biological fluids and tissues. Active targeting using drug attachment to a receptor is a powerful concept that has been probed for several decades, but progress remains very slow, and positive in vitro results are only too rarely confirmed in vivo. For instance antibody-targeted radiotherapy was shown to localize less than $0.01 \%$ of the administrated dose to the tumor [32]. Evaluation of dose-dependent targeting is essential for pharmacological evaluation, and receptor saturation often occurs at low dose. Biomarkers are required in various nanomedicine technologies to measure the efficacy and safety of these drugs, because only a few \% of drugs entering clinical investigation reach marketing approval [33]. Several families of new nanomaterials have attracted increased attention as nanovectors and theranostics in nanomedicine, in particular during the last decade:

- Carbon materials that include fullerene (mainly $\mathrm{C}_{60}$ ), single-wall and multi-wall carbon nanotubes (SWCNTs and MWCTs respectively) [34], graphene oxide (GO) and nanodiamond (ND) [35]. Although these materials are insoluble in most solvents, including aqueous media, they can be polyfunctionalized with solubilizing groups such as polyethylene glycol, etc. The carbon cores of the functionalized carbon materials are essentially used as a scaffold, and tumor targeting and imaging using Raman signatures have potential. Although the problem of safety concerning these cores must be addressed, the functional groups ensure protection and penetration into organs. Long-term toxicity remains an issue, however, and clinical tests should be crucial.

- Gold nanoparticles have a many centuries of historic tradition in therapeutics, but nanosciences has brought about novel theranostic concepts based on the medium-sensitive plasmonic absorption resulting from the visible and infrared light-induced collective oscillation of the surface electrons when the nanoparticle size is much smaller than the light wavelength [36,37]. Gold nanoparticle plasmons can be applied in various ways to nanomedicine [38-40], in particular photothermal therapy with gold nanorods and hollow gold nanoshells with plasmon bands in the near infrared region and various imaging techniques [37,40]. Gold nanoparticles indeed provide versatile scaffolds for cell surface sensing with the use of both specific recognition and array-based "chemical nose" approaches [41-43]. Passive tumor targeting with PEG for EPR effect and active targeting upon covalent linking to rhTNFa (CYT-6091) have reached anticancer clinical trials [44]. The preparation of gold nanoparticles and their functionalization are well controlled and reproducible, which is important for patenting, and the small size of these particles $(<10 \mathrm{~nm})$ represents an advantage compared with other nanoparticles that are probed for nanomedicine $[36,45]$. Although safety studies in vitro and in vivo are often contradictory, gold nanoparticles are considered as a standard for safety issues [46,47]. Silver and copper nanoparticles also present plasmonic properties, but the gold nanotechnology appears much superior to those of the lighter the group 11 elements. Nethertheless, "nanocrystalline silver" is well known for its established antimicrobial properties [48], although it is also cytotoxic [49].

- Super Paramagnetic Iron Oxide Nanoparticles (SPIONs), usually magnetite, $\mathrm{Fe}_{3} \mathrm{O}_{4}$, are widely explored [50], despite their toxicity [51], in combination with a magnet for magnetic resonance imaging (MRI) and tumor ablation by hyperthermia. This technique has reached clinical use and phase II investigation in brain cancer (multiform glioblastoma) and also clinical study of non-metastatic prostate cancer [52]. Other oxide nanoparticles include silica (usually mesostructured silica) that is used to encapsulate drugs or SPIONs [53,54].

- Quantum Dots (QD), binary semiconductor nanoparticles, are most often CdSe particles coated with ZnS or CdS. They are 2-10 nm dimension fluorescent imaging labels that are frequently used in nanomedicine [55,56] in spite of the toxicity of heavy metals [57].

- Polymers and other macromolecules including co-polymers, antibodies, proteins, aptamers and dendrimers are intensively studied as drug nanovectors in nanomedicine [58-62]. A number of successful polymers are biodegradable and used in pre-clinical and clinical studies [63]. 
Major advances have been published, but important obstacles still remain concerning the use of encapsulated drugs in polymer nanoparticles including "burst release", poor drug loading, and poor miscibility of some drugs with the polymer carrier [64]. Dendrimers that are cauliflower-shaped nano-scale macromolecules bearing many functional branch termini $[65,66]$ have considerable capacity to encapsulate drugs and traverse biological barriers [67-71]. The dendritic microbiocide Vivagel was evaluated clinically [72]. Other commercial dendrimers [73] include Ocuseal, a microbial barrier [74], gadomer-17, a dendritic MRI [75], Stratus CS, a cardiac biomarker [76], Alert Ticket for anthrax detection, and Qiagen for in vitro DNA transfection [77]. Clinical trials are slow, however. Challenging problems remaining are purity, reproducibility, biodegradability and biocompatibility [78].

- Various forms of liposomes have long been and remain among the most successful drug careers [79]. They include lipids, proteins, albumin, vesicles and related biopolymers and can involve combined drugs such as anti-cancer agents. Combination of imaging agents for diagnostics and drugs for therapy are examples called theranostics.

Many reviews cited in this introduction discuss the various clinical trials of these nano-drugs. Research in nanomedicine is exploding, but multi-phase clinical trials are very demanding. In the end, only a few nanodrug candidates successfully pass regulatory authority requirements. No doubt that interdisciplinary collaborations between biomedical scientists, chemists and biophysicists will in the future favor the arrival of more nanoengineered drugs on the market [80-84].

Conflicts of Interest: The author declares no conflict of interest.

\section{References}

1. European Science Foundation. Forward Look Nanomedicine: An EMRC Consensus Opinion 2005. Available online: http:/ / www.esf.org (accessed on 21 December 2015).

2. Peer, D.; Karp, J.M.; Hong, S.; Farokhzad, O.C.; Margalit, R.; Langer, R. Nanocarriers as an emerging platform for cancer therapy. Nat. Nanotechnol. 2007, 2, 751-760. [CrossRef] [PubMed]

3. Duncan, R. Polymer conjugates as anticancer nanomedicines. Nat. Rev. Cancer 2006, 6, 688-701. [CrossRef] [PubMed]

4. Picard, F.J.; Bergeron, M.J. Rapid theranostic in infectious diseases. Drug Discov. Today 2002, 7, 1092-1101. [CrossRef]

5. Bardhan, R.; Lal, S.; Joshi, A.; Halas, N.J. Theranosctic Shells: From Probe Design to Imaging and Treatment of Cancer. Acc. Chem. Res. 2011, 44, 936-946. [CrossRef] [PubMed]

6. Anconi, F. Panacae Aurea-Auro Potabile; Bibliopolio Frobeniano: Hamburg, Germany, 1618.

7. Macker, P.-J. Dictionnaire de Chymie; Lacombe: Paris, France, 1766.

8. Cooper, E.L. From Darwin and Metchnikoff to Burnet and Beyond. Contrib. Microbiol. 2008, 15, 1-11. [PubMed]

9. Ehrlich, P. Address in pathology. On chemiotherapy. Delivered before the 17th International Congress of Medicine. Br. Med. J. 1913, 16, 353-359. [CrossRef]

10. Gregoriadis, G.; Leathwood, P.D.; Ryman, B.E. Enzyme entrapment in liposomes. FEBS Lett. 1971, 14, 95-99. [CrossRef]

11. Bangham, A.D. Lipid bilayers and biomembranes. Annu. Rev. Biochem. 1972, 41, 753-776. [CrossRef] [PubMed]

12. Cornu, G.; Michaux, J.L.; Sokal, G.; Trouet, A. Daunorubicin-DNA: Further clinical trials in acute non-lymphoblastic leukemia. Eur. J. Cancer 1974, 10, 695-700. [CrossRef]

13. Ringsdorf, H. Structure and properties of pharmacologically active polymers. J. Polym. Sci. Polym. Symp. 1975, 51, 135-153. [CrossRef]

14. Hurwitz, E.; Levy, R.; Maron, R.; Wilchek, M.; Arnon, R.; Sela, M. The covalent binding of daunomycin and adriamycin to antibodies, with retention of both drug and antibody activities. Cancer Res. 1975, 35, 1175-1181. [PubMed]

15. Kreuter, J.; Speiser, P.P. In vitro studies of poly(methyl methacrylate) adjuvants. J. Pharm. Sci. 1976, 65, 1624-1627. [CrossRef] [PubMed] 
16. Couvreur, P.; Tulkens, P.; Roland, M.; Trouet, A.; Speiser, P. Nanocapsules: A new type of lysosomotropic carrier. FEBS Lett. 1977, 84, 323-326. [CrossRef]

17. Duncan, R.; Kopecek, J. Soluble synthetic polymers as potential drug carriers. Adv. Polym. Sci. 1984, 57, 51-101.

18. Davis, F.F. The origin of pegnology. Adv. Drug Deliv. Rev. 2002, 54, 457-458. [CrossRef]

19. Trouet, A.; Masquelier, M.; Baurain, R.; Deprez-de Campeneere, D. A covalent linkage between daunorubicin and proteins that is stable in serum and reversible by lysosomal hydrolases, as required for a lysosomotropic drug-carrier conjugate: In vitro and in vivo studies. Proc. Natl. Acad. Sci. USA 1982, 79, 626-629. [CrossRef] [PubMed]

20. Gros, L.; Ringsdorf, H.; Schupp, H. Polymeric antitumour agents on a molecular and cellular level. Angew. Chem. Int. Ed. 1981, 20, 301-323. [CrossRef]

21. Dequeker, J.; Verdickt, W.; Gevers, G.; Vanschoubroek, K. Longterm experience with oral gold in rheumatoid arthritis and psoriatic arthritis. Clin. Rheumatol. 1984, 3 (Suppl. 1), 67-74. [CrossRef] [PubMed]

22. Russell, A.D.; Hugo, W.B. Antimicrobial activity and action of silver. Prog. Med. Chem. 1994, 31, 351-370. [PubMed]

23. Duncan, R.; Gaspar, R. Nanomedicines under the microscope. Mol. Pharm. 2011, 8, 2101-2141. [CrossRef] [PubMed]

24. Garcia-Garcia, E.; Andrieux, K.; Gil, S.; Couvreur, P. Colloidal carriers and blood-brain barrier (BBB) translocation: A way to deliver drugs to the brain? Int. J. Pharm. 2005, 298, 274-292. [CrossRef] [PubMed]

25. Wiwattanapatapee, R.; Carreno-Gomez, B.; Malik, N.; Duncan, R. Anionic PAMAM dendrimers rapidly cross adult rat intestine in vitro: A potential oral delivery system. Pharm. Res. 2000, 17, 991-998. [CrossRef] [PubMed]

26. Boczkowski, J.; Hoet, P. What's new in nanotoxicology? Implications for public health from a brief review of the 2008 literature. Nanotoxicology 2010, 4, 1-14. [CrossRef] [PubMed]

27. Astruc, D. Research Avenues on Dendrimers towards Molecular Biology: From Biomimetism to Medicinal Engineering. C. R. Acad. Sci. 1996, 322, 757-766.

28. Szebeni, J. Complement activation-related pseudoallergy: A new class of drug-induced acute immune toxicity. Toxicology 2005, 216, 106-121. [CrossRef] [PubMed]

29. Farrell, D.; Ptak, K.; Panaro, N.J.; Grodzinski, P. Nanotechnology-based cancer therapeutics-promise and challenge-lessons learned through the NCI Alliance for Nanotechnology in Cancer. Pharm. Res. 2011, 28, 273-278. [CrossRef] [PubMed]

30. Matsumura, Y.; Maeda, H. A new concept for macromolecular therapies in cancer chemotherapy: Mechanism of tumouritropic accumulation of proteins and the antitumour agent SMANCS. Cancer Res. 1986, 6, 6387-6392.

31. Folkman, J. Angiogenesis: An organizing principle for drug discovery? Nat. Rev. Drug Discov. 2007, 6, 273-286. [CrossRef] [PubMed]

32. Jain, M.; Venkatraman, G.; Batra, S.K. Optimization of radio-immunotherapy of solid tumors: Biological impediments and their modulation. Clin. Cancer Res. 2007, 13, 1374-1382. [CrossRef] [PubMed]

33. Tan, D.S.; Thomas, G.V.; Garrett, M.D.; Banerji, U.; de Bono, J.S.; Kaye, S.B.; Workman, P. Biomarker-driven early clinical trials in oncology: A paradigm shift in drug development. Cancer J. 2009, 15, 406-420. [CrossRef] [PubMed]

34. Bianco, A.; Kostarelos, K. Application of carbon naotubes in drug delivery. Curr. Opin. Chem. Biol. 2005, 9, 674-679. [CrossRef] [PubMed]

35. Lim, D.J.; Sim, M.; Oh, L.; Park, H. Carbon-based drug delivery carriers for cancer therapy. Arch. Pharm. Res. 2014, 37, 43-52. [CrossRef] [PubMed]

36. Daniel, M.-C.; Astruc, D. Gold Nanoparticles: Assembly, Supramolecular Chemistry, Quantum-size Related Properties, and Applications towards Biology, Catalysis and Nanotechnology. Chem. Rev. 2004, 104, $293-346$. [CrossRef] [PubMed]

37. Dreaden, E.C.; Alkilany, A.M.; Huang, X.; Murphy, C.J.; El-Sayed, M.A. The golden age: Gold nanoparticles for biomedicine. Chem. Soc. Rev. 2012, 41, 2740-2779. [CrossRef] [PubMed]

38. Boisselier, E.; Astruc, D. Gold Nanoparticles in Nanomedicine: Preparations, Diagnostic, Therapy and Toxicity. Chem. Soc. Rev. 2009, 38, 1759-1782.

39. Llevot, A.; Astruc, D. Application of gold nanoparticles to the diagnostic and therapy of cancer. Chem. Soc. Rev. 2012, 41, 242-257. [CrossRef] [PubMed] 
40. Hirsch, L.R.; Stafford, R.J.; Bankson, J.A.; Shershen, S.R.; Rivera, B.; Price, R.E.; Hazle, J.D.; Halas, N.J.; West, J.L. Nanoshell-mediated near-infrared thermal therapy of tumors under magnetic resonance guidance. Proc. Nat. Acad. Sci. USA 2003, 100, 13549-13554. [CrossRef] [PubMed]

41. Saha, K.; Agasti, S.S.; Kim, C.; Rotello, V.M.; Li, X.N. Gold Nanoparticles in Chemical and Biological Sensing. Chem. Rev. 2012, 112, 2739-2779. [CrossRef] [PubMed]

42. Kim, S.T.; Saha, K.; Kim, C.; Rotello, V.M. The Role of Surface Functionality in Determining Nanoparticle Cytotoxicity. Acc. Chem. Res. 2013, 46, 681-691. [CrossRef] [PubMed]

43. Jiang, Z.; Le, N.D.B.; Gupta, A.; Rotello, V.M. Cell surface-based sensing with metallic nanoparticles. Chem. Soc. Rev. 2015, 44, 4264-4274. [CrossRef] [PubMed]

44. Libutti, S.K.; Paciotti, G.F.; Byrnes, A.A.; Alexander, H.R., Jr.; Gannon, W.E.; Walker, M.; Seidel, G.D.; Yuldasheva, N.; Tamarkin, L. Phase I and pharmacokinetic studies of CYT-6091, a novel PEGylated colloidal gold-rhTNF nanomedicine. Clin. Cancer Res. 2010, 16, 6139-6149. [CrossRef] [PubMed]

45. Zhao, P.; Li, N.; Astruc, D. State of the Art in the Synthesis of Gold Nanoparticles. Coord. Chem. Rev. 2013, 257, 638-665. [CrossRef]

46. Alkilany, A.M.; Murphy, C.J. Toxicity and cellular uptake of gold nanoparticles: What we have learned so far? J. Nanopart. Res. 2010, 12, 2313-2333. [CrossRef] [PubMed]

47. Li, N.; Zhao, P.; Astruc, D. The multiple shapes of anisotropic gold nanoparticles: Synthesis, properties, applications and toxicity. Angew. Chem. Int. Ed. 2014, 52, 1756-1789. [CrossRef] [PubMed]

48. Elliott, C. The effects of silver dressings on chronic and burns wound healing. Br. J. Nurs. 2010, 19, S32-S36. [CrossRef] [PubMed]

49. Poon, V.K.; Burd, A. In vitro cytotoxicity of silver: Implication for clinical wound care. Burns 2004, 30, 140-147. [CrossRef] [PubMed]

50. Gupta, A.K.; Gupta, M. Synthesis and Surface Engineering of Iron oxide for biomedical applications. Biomaterials 2005, 26, 3995-4021. [CrossRef] [PubMed]

51. Mahmoudi, M.; Simchi, A.; Imani, M.; Shokrgozar, M.A.; Milani, A.S.; Häfeli, U.O.; Stroeve, P. A new approach for the in vitro identification of the cytotoxicity of superparamagnetic iron oxide nanoparticles. Colloids Surf. B 2010, 75, 300-339. [CrossRef] [PubMed]

52. Jin, R.; Lin, B.B.; Li, D.Y.; Ai, H. Superparamagnetic iron oxide nanoparticles for MR imaging and therapy: Design considerations and clinical applications. Curr. Opin. Pharmacol. 2014, 18, 18-27. [CrossRef] [PubMed]

53. Liong, M.; Lu, J.; Kovochich, M.; Xia, T.; Ruehm, S.G.; Nel, A.E.; Tamanoi, F.; Zink, J.I. Multifunctional inorganic nanoparticles for imaging, targeting, and drug delivery. ACS Nano 2008, 2, 889-896. [CrossRef] [PubMed]

54. Li, Z.; Barnes, J.C.; Bosoy, A.; Soddart, J.F.; Zink, J.L. Mesoporous silica nanoparticles in biomedical applications. Chem. Soc. Rev. 2012, 41, 2590-2605. [CrossRef] [PubMed]

55. Gao, X.H.; Cui, Y.Y.; Levenson, R.M.; Chung, L.W.K.; Nie, S.M. In vivo cancer targeting and imaging with semiconductor quabntum dots. Nat. Biotechnol. 2004, 22, 969-976. [CrossRef] [PubMed]

56. Zrazhevskiy, P.; Sena, M.; Gao, X. Designing multifunctional quantum dots for bioimaging, detection, and drug delivery. Chem. Soc. Rev. 2010, 39, 4326-4354. [CrossRef] [PubMed]

57. Templeton, D.M.; Liu, Y. Multiple roles of cadmium in cell death and survival. Chem. Biol. Interact. 2010, 188, 267-275. [CrossRef] [PubMed]

58. Duncan, R. The dawning era of polymer therapeutics. Nat. Rev. Drug Discov. 2003, 2, 347-360. [CrossRef] [PubMed]

59. Duncan, R.; Vicent, M.J. Polymer therapeutics-prospects for 21st century: The end of the beginning. Adv. Drug Deliv. Rev. 2013, 65, 60-70.

60. Matsumura, Y. Poly (amino acid) micelle nanocarriers in preclinical and clinical studies. Adv. Drug Deliv. Rev. 2008, 60, 899-914. [CrossRef] [PubMed]

61. Dong, R.J.; Zhou, Y.F.; Huang, X.H.; Zhu, X.Y.; Lu, Y.F.; Shen, J. Functional Supramolecular Polymers for Biomedical Applications. Adv. Mater. 2015, 27, 498-526. [CrossRef] [PubMed]

62. Keefe, A.D.; Pai, S.; Ellington, A. Aptamers as therapeutics. Nat. Rev. Drug Discov. 2010, 9, 537-550. [CrossRef] [PubMed]

63. Brigger, I.; Dubenet, C.C.; Couvreur, P. Nanoparticles in cancer therapy and diagnosis. Adv. Drug. Deliv. 2002, 54, 631-651. [CrossRef] 
64. Delplace, V.; Couvreur, P.; Nicolas, J. Recent trends in the design of anticancer polymer prodrug nanocarriers. Polym. Chem. 2014, 5, 1529-1544. [CrossRef]

65. Tomalia, D.A.; Naylor, A.M.; Goddard, W.A., III. Starburst dendrimers: Molecular level control of size, shapes, surface chemistry, topology and flexibility from atoms to macroscopic matter. Angew. Chem. Int. Ed. 1990, 29, 138-175. [CrossRef]

66. Astruc, D.; Boisselier, E.; Ornelas, C. Dendrimers Designed for Functions: From Physical, Photophysical and Supramolecular Properties to Applications in Sensing, Catalysis, Molecular Electronics, Photonics and Nanomedicine. Chem. Rev. 2010, 110, 1857-1959. [CrossRef] [PubMed]

67. Lee, C.C.; MacKay, J.A.; Fréchet, J.M.; Szoka, F.C. Designing dendrimers for biological applications. Nat. Biotechnol. 2005, 23, 1517-1526. [CrossRef] [PubMed]

68. Baker, J.R., Jr. Dendrimer-based nanoparticles for cancer therapy. Hematology 2009, 2009, 708-719. [CrossRef] [PubMed]

69. Svenson, S. Dendrimers as versatile platform in drug delivery applications. Eur. J. Pharm. Biopharm. 2009, 71, 445-462. [CrossRef] [PubMed]

70. Kesharwani, P.; Jain, K.; Jain, N.K. Dendrimers as nanocarriers for drug delivery. Prog. Polym. Sci. 2014, 39, 268-307. [CrossRef]

71. Kurniasih, I.N.; Keilitz, J.; Haag, R. Dendritic nanocarriers based on hyperbranched polymers. Chem. Soc. Rev. 2015, 44, 4145-4164. [CrossRef] [PubMed]

72. Tyssen, D.; Henderson, S.A.; Johnson, A.; Sterjovski, J.; Moore, K.; La, M.; Zanin, J.; Sonza, S.; Karellas, P.; Giannis, M.P.; et al. Structure activity relationship of dendrimer microbicides with dual action antiviral activity. PLoS ONE 2010, 5, e12309. [CrossRef] [PubMed]

73. Sharma, A.; Kakkar, A. Designing Dendrimers and Miktoarm Polymers Based Multi-tasking Nanocarriers for Efficient Medical Therapy. Molecules 2015. [CrossRef] [PubMed]

74. Uy, H.S.; Kenyon, K.R. Surgical outcomes after application of a liquid adhesive ocular bandage to clear corneal incisions during cataract surgery. J. Cataract. Refract Surg. 2013, 39, 1668-1674. [CrossRef] [PubMed]

75. Misselwitz, B.; Schmitt-Willich, H.; Ebert, W.; Frenzel, T.; Weinmann, H.-J. Pharmacokinetics of Gadomer-17, a new dendritic magnetic resonance contrast agent. MAGMA 2001, 12, 128-134. [CrossRef] [PubMed]

76. Altinier, S.; Mion, M.; Cappelletti, A.; Zaninotto, M.; Plebani, M. Rapid Measurement of Cardiac Markers on Stratus CS. Clin. Chem. 2000, 46, 991-993. [PubMed]

77. Kong, H.-H.; Pollard, T.D. Intracellular localization and dynamics of myosin-II and myosin-IC in live Acanthamoeba by transient transfection of EGFP fusion proteins. J. Cell Sci. 2002, 115, 4993-5002. [CrossRef] [PubMed]

78. Duncan, R.; Izzo, L. Dendrimer toxicity and biocompatibility. Adv. Drug Deliv. Rev. 2005, 57, $2215-2237$. [CrossRef] [PubMed]

79. Allen, T.M.; Cullis, P.R. Liposomal drug delivery systems: From concepts to clinical applications. Adv. Drug. Deliv. Rev. 2013, 65, 36-48. [CrossRef] [PubMed]

80. Zhao, P.; Astruc, D. Docetaxel nanotechnology in anti-cancer therapy. ChemMedChem 2012, 7, $952-972$. [CrossRef] [PubMed]

81. Zhang, Y.; Chan, H.F.; Leong, Kam W. Advanced material processing for drug delivery. The past and the future. Adv. Drug Deliv. Rev. 2013, 65, 104-120. [CrossRef] [PubMed]

82. Bertrand, N.; Wu, J.; Xu, X.; Kamaly, N.; Farokhzad, O.C. Cancer nanotechnology: The impact of passive and active targeting in the era of modern cancer biology. Adv. Drug. Deliv. Rev. 2014, 66, 2-25. [CrossRef] [PubMed]

83. Wicki, A.; Witzigmann, D.; Balasubramanian, V.; Huwyler, J. Nanomedicine in cancer therapy: Challenges, opportunities, and clinical applications. J. Control. Release 2015, 200, 138-157. [CrossRef] [PubMed]

84. Tong, R.; Langer, R. Nanomedicines targeting the tumor environment. Cancer J. 2015, 21, 314-321. [CrossRef] [PubMed]

(C) 2015 by the author; licensee MDPI, Basel, Switzerland. This article is an open access article distributed under the terms and conditions of the Creative Commons by Attribution (CC-BY) license (http://creativecommons.org/licenses/by/4.0/). 